\title{
CO-INTEGRATION AND CAUSALITY RELATIONSHIP BETWEEN ENERGY CONSUMPTION AND ECONOMIC GROWTH: FURTHER EMPIRICAL EVIDENCE FOR NIGERIA
}

\author{
Clement A. U. Ighodaro \\ Department of Economics, University of Lagos, Akoka, \\ Yaba, Lagos, Nigeria \\ E-mail: clemigho2006@yahoo.com \\ Received 26 February 2009; accepted 5 January 2010
}

\begin{abstract}
The Paper re - examined co-integration and causality relationship between energy consumption and economic growth for Nigeria using data covering the period 1970 to 2005. Unlike previous related study for Nigeria, different proxies of energy consumption (electricity demand, domestic crude oil consumption and gas utilization) were used for the estimation. It also included government activities proxied by health expenditure and monetary policy proxied by broad money supply though; emphasis was on energy consumption. Using the Johansen co-integration technique, it was found that there existed a long run relationship among the series. It was also found that all the variables used for the study were I(1). Furthermore, unidirectional causality was established between electricity consumption and economic growth, domestic crude oil production and economic growth as well as between gas utilization and economic growth in Nigeria. While causality runs from electricity consumption to economic growth as well as from gas utilization to economic growth, it was found that causality runs from economic growth to domestic crude oil production. Therefore, conservation policy regarding electricity consumption and gas utilization would harm economic growth in Nigeria while energy conservation policy as regards domestic crude oil consumption would not.
\end{abstract}

Keywords: Economic growth, Gas Utilization, Crude Oil consumption, Johansen cointegration.

Reference to this paper should be made as follows: Ighodaro, C. A. U. 2010. Co-integration and causality relationship between energy consumption and economic growth: further empirical evidence for Nigeria, Journal of Business Economics and Management 11(1): 97-111.

\section{Introduction}

Several papers have examined the empirical link between energy consumption and economic growth. Most of these studies differ in their methodology and data used. While some are country specific studies, others used several countries in their study at the same time. Even with recent literatures, empirical evidence is still mixed, and whether energy consumption Granger causes economic growth or the reverse is still to be debated. The non - consensus on the causality between energy and output might be because different 
economies have different energy consumption patterns as well as different sources of energy which might have varying impacts on economic growth.

As documented in Chontanawat et al. (2006), Jumbe (2004) stated that if causality runs from energy consumption to economic growth, then it implies that an economy is energy dependent. On the other hand, if causality only runs from economic growth to energy consumption, it means that an economy does not depend on energy. Hence as noted by Masih, A. M. M. and Masih, R. (1997) and Ighodaro and Ovenseri-Ogbomo (2008) amongst others, energy conservation policies may be implemented with no adverse effect on growth and development as well as employment. Furthermore, if there is 'neutrality hypothesis' that is, if there is no causality in either direction, it means that energy consumption is not correlated with economic growth, so that energy conservation policies may be carried out without adversely affecting the economy.

Most previous studies on causality relationship between energy and economic growth used bivariate Granger causality tests to draw inference including previous study by Ighodaro and Ovenseri-Ogbomo (2008) for Nigeria. This approach, although appealing for its simplicity, is problematic on at least two accounts. First, single-equation ECMs are only valid given exogeneity assumptions (Bannered et al. 1993). To test the relationships between two or more series, bivariate specifications cannot capture all relevant information. For example, Glasure (2002) argued that the empirical examination of the association between energy and real income must also include money, government spending and the price of energy. Hence Glasure used Gross Domestic product, energy consumption, government expenditure, money supply and oil price in his study. To solve this problem of bivariate specification, the test for this paper is carried out in a multivariate framework proposed in the Johansen test (Johansen 1991).

Contrary to the earlier study of Ighodaro and Ovenseri-Ogbomo (2008), Omotor (2008) and Olusegun (2008) for Nigeria and follow from the studies of Yang (2000) and Glasure (2002) for Korea, the study re-examined causality relationship between energy consumption and economic growth for Nigeria by including monetary policy variable and another representing government activities as well as using the Johansen co-integration technique and the multivariate Granger causality method. Section two considers literature review on causality relationship between energy consumption and economic growth, energy situation in Nigeria is discussed in section three while section four examined methodology and discussion of results. Section five concludes.

\section{Literature Review on Causality Relationship between Energy Consumption and Economic Growth}

Previous researchers used different econometric methodologies to test the relationship among growth, income and energy consumption. Rasche and Tatom (1977), Kraft, J. and Kraft, A. (1978), Berndt (1978), Akarca and Long (1980), Proops (1984), Yu and Hwang (1984) as well as Nachane et al. (1988) were the earliest researchers in this area. Rasche and Tatom (1977) specified a production function for the United States. They included energy as explanatory variable along with land, labour and capital. They 
showed that energy price increases induced declining trends on potential gross national product over the study period.

Study by Kraft, J. and Kraft, A. (1978) found a strong causality running unidirectionally from gross national product to energy consumption using annual data for 1947 to 1974. They therefore argued that "while the level of economic activities may influence energy consumption, the level of gross energy consumption has no causal influence on economic activities. Akarca and Long (1980) contested Kraft, J. and Kraft, A. (1978) result; they used data for the United States for the period 1950 - 1968 and 1970. Using the Sims' technique for energy and gross national product, they found no causal relationship between gross national product and energy consumption.

Yu and Hwang (1984) confirmed the absence of any causality between energy consumption and gross national product over the sample period 1947 to 1979 for the United States. The same procedure revealed unidirectional causality running from gross national product to energy consumption over the sample period. Yu and Choi (1985) found different results for different economies. They found no causality relationship between gross national product and energy consumption for the USA, UK and Poland. On the other hand, they found unidirectional causality from gross national product to energy consumption for South Korea and from energy consumption to gross national product in the Philippines.

Erol and Yu (1988) used gross national product and energy consumption for West Germany using data for 1952 - 1982, Italy; 1952 to 1982, Canada; 1952 to 1982, France and the UK; 1952 to 1982 . They found bidirectional causality for Japan, energy consumption causes gross national product for Canada, real gross national product causes energy consumption for West Germany and Italy and no causality was found for UK and France. Nachane et al. (1988) based on the Engle - Granger cointegration methodology, found long run relationship between energy consumption and economic growth for eleven developing countries and five developed countries. Also, using similar methodology, Glasure and Lee (1997) for South Korea and Singapore found bidirectional causality while Cheng and Lai (1997) found no long run relationship for Taiwan. Abosedra and Baghstain (1989) documented that direct Granger test should be used and they concluded that for all sample periods tested; 1947 to 1972,1947 to 1974,1947 to 1979 and 1947 to 1987, there was a unidirectional causality between gross national product and economic growth.

Yu and Jin (1992) used employment data as a third variable in explaining the link between energy consumption and gross national product. They used monthly data over the period 1994: 1: 1990: 4 for the United States and they did not find any evidence of co-integration. With this analysis, they concluded that energy restrictions do not harm economic growth in the United States and that energy conservation has no clear impact on employment.

Masih, A. M. M. and Masih, R. (1996, 1997, 1998) used the Johansen methodology to examine energy use and economic growth using several Asian economies. In Masih, A. M. M. and Masih, R. (1996), they found a long run energy income relationship for 
India, Pakistan and Indonesia but no long run relationship for Malaysia, Singapore and the Philippines. Masih, A. M. M. and Masih, R. (1997) used income, energy consumption and energy prices for Korea; 1955 to 1991 and Taiwan; 1952 to 1992, they found bidirectional causality. On the other hand, Masih, A. M. M. and Masih, R. (1998) found a relationship but no evidence of directions for Thailand and Sri Lanka. Reddy and Yanagida (1998) considered energy consumption and economic activities in Fiji and concluded that total energy use in the commercial sector was sharply reduced as a result of a structural change in the economy and an increase in the efficiency of energy use. Furthermore, using gross domestic product and energy consumption with co-integration and Granger causality, Cheng (1999) for India used data for 1952 to 1995, Cheng and Wong (2001) for Singapore used data for 1975 to 1995; Aqeel and Butt (2001) for Pakistan and data for 1955 to 1996 applied the technique of co-integration and Hsiao's version of Granger causality. They found that economic growth Granger causes energy consumption in their respective studies. Also for Taiwan, Hwang and Gum (1992) found bidirectional causality while Cheng and Lee (1997) found no long run relationship. On the other hand, Yang (2000) used different types of energy consumption; oil, gas, coal and power to test for the causal link with gross domestic product in Taiwan. Using data for 1954 to 1997, Yang (2000) found unidirectional causality from economic growth to coal consumption and concluded that different forms of energy exhibited different direction of causality.

A slightly different studies from the one discussed above are those of Ferguson et al. (2000) and Hannesson (2002). Ferguson et al. (2000) studied the relationship between electricity use and economic development in over one hundred countries. Their general conclusion is that wealthy countries have stronger correlation between electricity use and wealth creation than there is between total energy use and wealth. Hannesson (2002) on his part took a more general view when he considered increased energy use and economic growth in the later part of the $20^{\text {th }}$ century. He divided the time span into five sub - periods based on the development of oil prices. He found that energy use tend to grow more slowly than gross domestic product in rich countries while the reverse is the case for poor countries.

Hondroyiannis et al. (2002) studied the link between energy consumption, gross domestic product and the consumer price index (CPI) for Greece. They used annual data over the period 1960 to 1996 and found evidence for long run bi - directional causality between energy consumption (total and industrial) gross domestic product. On the other hand, there was no causality between residential use of energy and gross domestic product. Another study is Soytas and Sari (2003). They obtained mixed results for the countries they studied. While they found bidirectional causality in Argentina, they found causality running from gross domestic product to energy consumption in Italy and Korea and from energy consumption to gross domestic product in Turkey, France, Germany and Japan. Ghosh (2002) carried out a study for India using annual data for the period 1950 to 1997 . He found no co-integration but argued that there is unidirectional causality from economic growth to electricity consumption. However, the results contradicted Granger (Granger 1986) postulation that there cannot be causality between non - stationary variables that are not co-integrated. 
Glasure (2002) employed a five variable Vector Error Correction Methodology to study causality between economic growth and energy consumption in Korea. Government expenditure was used as a proxy for government activity, money supply was used as proxy for monetary policy and oil prices are included as important factor explaining the causality using data for 1961 to 1990 . Structural breaks of two oil price pikes were further included as dummies in the model. He found bi directional causality and the oil price was found to have the biggest impact on energy growth and energy consumption.

Soytas and Sari (2003) tested the time series properties of energy consumption and gross domestic product. They reexamined the causality relationship between the two series in the top ten emerging markets - excluding China due to lack of data and $G-7$ countries. They found bidirectional causality for Argentina and causality running from gross domestic product to energy consumption in Italy and Korea and from energy consumption to gross domestic product in Turkey, France, Germany and Japan. This implies that energy conservation may harm economic growth in the last four countries.

Oh and Lee (2004) also studied South Korea but shifted the data set ten years ahead to consider the period $1970-1999$. They considered energy, labour and capital to be important production factors for generating gross domestic product. They used a Vector Error Correction methodology and found bi - directional causation between energy and gross domestic product. Furthermore, Jumbe (2004) also found bi - directional causality between energy demand and gross domestic product in Malawi using the error correction test. Sari and Soytas (2004) applied the generalized forecast error variance decomposition technique. They concluded that energy consumption is almost as important as employment in explaining the variance in the growth of national income in Turkey. Also for Turkey, Altinay and Karagol (2005) applied a series of unit root tests to verify if there is causality between gross domestic product and energy for the period 1950 to 2000. While they showed that energy consumption and gross domestic product have unit root in Turkey, they also found structural break in the data. They concluded that there is no causality between energy consumption and economic growth.

Ghali and El-Sakka (2004) used the Johansen methodology based on data for Canada. They found that the short run dynamics of variables indicated that causality ran in two directions between output growth and energy use. They further concluded that energy can be considered a limiting factor to output growth in Canada. Also, Wolde-Rufael (2004) used gross domestic product, total and disaggregated industrial energy consumption for Shanghai using data for 1952 to 1999. It was found that energy consumption; total and disaggregated Granger cause real gross domestic product.

Squalli and Wilson (2006) study was a little bit different. They considered a bounds analysis of electricity consumption and economic growth in the Cooperation Council for the Arab States of the Gulf (GCC). They tested the electricity consumption - income growth hypothesis for the six members of the GCC countries. Using the bounds test suggested by Pesaran et al. (2001) to test for long run relationship and the non- causality approach suggested by Toda and Yamamoto (1995). They found evidence of a long run relationship between electricity consumption and economic growth for all GCC 
countries. Also, they found support for the efficacy of energy conservation measures in five of the six countries with Qatar as the only exception.

Sica (2007) for Italy investigated the possibility of "energy demand - led growth" and "growth- driven energy demand" hypothesis using the error correction model. The result of the study did not reveal any causality linkage. Though, the standard Granger test found evidence of unidirectional causality running from energy to gross domestic product. Furthermore, Alper and Atilla (2007) used the wavelet analysis and found that in the short run, there is feedback relationship between gross national product and energy consumption. However, in the long run, gross national product led to energy consumption. Ighodaro and Ovenseri-Ogbomo (2008) for Nigeria used data for 1970 to 2003 and using the co integration and bivariate Granger causality technique. They found unidirectional causality between energy consumption (electricity demand) and economic growth with causality running from energy consumption to economic growth. They concluded that a well designed energy conservation policy can be an effective tool in managing the energy sector in Nigeria. Contrary to the result, Omotor (2008) also for Nigeria found a bidirectional relationship between coal production and economic growth as well as between economic growth and electricity use while Olusegun (2008) used a Bound testing cointegration approach and found no causality relationship between electricity consumption and economic growth. In a related, though, different study, Çelik and Özerkek (2009) examined the relationship between consumer confidence, personal consumption and other relevant economic and financial variables for nine European Union countries. Using panel data analysis, they found the existence of a long run relationship and conclude that consumers are able to detect early signals about future rates of economic growth as they contribute through the consumption channel.

\section{Energy Situation in Nigeria}

Nigeria is endowed with sufficient energy resources to meet its present and future development requirements. The country possesses the world's sixth largest reserve of crude oil. It is increasingly an important gas province with proven reserves nearly 5000 billion cubit meters. Coal and lignite reserves are estimated to be 2.7 billion tons while tar sand reserves represent 31 billion barrels of oil equivalent. Identified hydroelectricity sites have an estimated capacity of about 14, $250 \mathrm{MW}$. Nigeria has significant biomass resources to meet both traditional and modern energy uses, including electricity generation (Federal Republic of Nigeria 2006). Table 1 below shows Nigeria's energy reserves/ potentials.

Electricity system in Nigeria centers on Power Holding Company of Nigeria. This is because, it accounts for about $98 \%$ of total electricity generation (Central Bank of Nigeria 2000). Power generation by other agencies such as Nigerian Electricity Supply Company relies on thermal power for electricity generation unlike the Power Holding Company of Nigeria which relies on both hydro and thermal power. However, electricity is also a consumer of fuel and energy like coal, fuel oil, natural gas and diesel oil. The importance of these sources of energy and fuel for generating electricity has been decreasing in recent years. However, hydro-power which is relatively cheaper than these 
Table 1. Nigeria's energy reserves / potentials

\begin{tabular}{llll}
\hline Resource & Reserve & Reserves Billion Tonnes & \% Fossil \\
\hline Crude oil & 33 billion bbl & 4.488 & 31.1 \\
\hline Natural gas & $\begin{array}{l}4502.4 \text { billion } \mathrm{m}^{3} \\
(159 \text { trillion scf) }\end{array}$ & 3.859 & 26.7 \\
\hline Coal and Lignite & 2.7 billion tonnes & 1.882 & 13.0 \\
\hline Tar Sands & 31 billion bbl oil equivalent & 4.216 & 29.2 \\
\hline Sub - Total (Fossil Fuels) & $\mathbf{1 4 . 4 4 5}$ & $\mathbf{1 0 0 . 0}$ \\
\hline Hydropower, Large scale & $10,000 \mathrm{MW}$ & & \\
\hline Hydropower, small scale & $734 \mathrm{MW}$ & Provisional & \\
\hline Fuel wood & $13,071,464$ has (forest & Estimate & \\
\hline Animal waste & $61 \mathrm{million}$ tonnes $/ \mathrm{yr}$ & Estimate & \\
\hline Crop Residue & $83 \mathrm{million}$ tonnes/yr & Estimate & \\
\hline Solar Radiation & $3.5-7.0 \mathrm{kWh} / \mathrm{m}^{2}$ & & \\
\hline Wind & $2-4 \mathrm{~m} / \mathrm{s}$ (annual average) & & \\
\hline
\end{tabular}

Source: Renewable Energy Mater Plan in Federal Republic of Nigeria (2006) p. 30

sources had grown to be more important than other sources (Olayide 1976). However, in recent times, the Power Authority generates electricity through a mix of both thermal and hydro systems. All the power stations, distribution stations and sub- stations are specially interlinked by a transmission network popularly known as the national grid. The entire electricity generated nation-wide is pooled into the National Control Centre, Osogbo from where electricity is distributed to all parts of Nigeria.

In terms of consumption of electricity, this is classified into three groups; industrial and residential consumption as well as consumption for street light purposes. As at 1970, total electricity consumption stood at 145.3 megawatt per hour, this increased to about 536.9 megawatt per hour as at 1980 . However, as at 2005, total electricity consumption has increased to 1,873.1 megawatt per hour (CBN 2007). On the generation side, this was 176.6 megawatt per hour in 1970 and increased to 815.1 megawatt per hour in 1980. By the end of 2005, total electricity generation stood at 2,997.3 megawatt per hour (CBN 2007). Comparing per capita power generation to that of other countries, Nigeria appears to be the lowest among the countries as shown in table 2 below while USA has the highest per capita electricity generation.

Inspite of the contribution of electricity to total gross domestic product, it is still bedeviled with several problems in Nigeria. The existing facilities of Power Holding Company of Nigeria notwithstanding, electricity supply in the country has remained very unavailable. According to Randle (2007), another problem is poor funding and inadequate infrastructural development. 
C. A. U. Ighodaro. Co-integration and Causality Relationship between Energy Consumption ...

Table 2. Per Capita power generation for some selected countries (2007)

\begin{tabular}{lccc}
\hline Country & $\begin{array}{c}\text { Electricity Generated } \\
(\mathrm{Mw})\end{array}$ & $\begin{array}{c}\text { Population }(2007 \\
\text { estimate) }\end{array}$ & $\begin{array}{c}\text { (\%) Electricity } \\
\text { per Capital }\end{array}$ \\
\hline Nigeria & $5,898.00$ & $135,031.160$ & 0.44 \\
\hline USA & $942,178.00$ & $301,139,950$ & 31.29 \\
\hline India & $131,431.00$ & $1,129,866,200$ & 1.16 \\
\hline South Africa & $40,481.00$ & $43,997,828$ & 9.20 \\
\hline Brazil & $86,504.00$ & $190,010,650$ & 4.55 \\
\hline Ghana & $1,748.00$ & $22,931,299$ & 0.76 \\
\hline UK & $76,187.00$ & $60,776,238$ & 12.54 \\
\hline Mexico & $49,533.00$ & $104,908,000$ & 4.72 \\
\hline
\end{tabular}

Source: Randle (2007) in Vanguard Vol. 23

\section{Methodology}

\section{Stationarity Test}

All the variables were tested at levels for stationarity using the Augmented DickeyFuller (ADF) test. Consider the equation below:

$$
\Delta \lambda_{t}=\alpha_{1}+\alpha_{2}+\phi \lambda_{t-1}+\beta_{i} \sum_{i=1}^{m} \Delta \lambda X_{t-i}+\varepsilon_{t} .
$$

Where $\lambda_{t}$ is our variable of interest $\Delta$ is the difference operator, $t$ is the time trend and $\varepsilon$ is the white noise residual of zero mean and constant mean and constant variance; $\left(\alpha_{1}, \alpha_{2}, \beta_{1}, \ldots \beta_{m}\right)$ is a set of parameters to be estimated. The null and the alternative hypotheses in the unit root tests are:

$$
\begin{gathered}
H_{0}: \phi \neq 0\left(\lambda_{t} \text { is non - stationary }\right) . \\
H_{1}: \phi=0\left(\left(\lambda_{t} \text { is stationary }\right) .\right.
\end{gathered}
$$

The test revealed that all the variables used are I(1) at 1\%,5\% and $10 \%$ significant levels respectively as shown in table 3 .

\section{Figures in parenthesis are the critical values}

Where:

LGDP is log of growth rate of gross domestic product representing economic growth LXHEA is log of health expenditure proxy for government activities

LMSS is log of broad money supply proxy for monetary policy

LELEC is the log of electricity consumption (energy consumption)

LCROL is the log of domestic consumption of crude oil (energy demand)

LGUT is the log of gas utilization in Nigeria (energy demand)

All the data used were extracted from various volumes of Central Bank of Nigeria (2003, 2004 and 2007) Statistical Bulletin. 
Table 3. Result of Unit Root Test

\begin{tabular}{|c|c|c|c|c|c|c|}
\hline Variable & $\begin{array}{c}\text { Only } \\
\text { Intercept }\end{array}$ & $\begin{array}{c}\text { Level of } \\
\text { Significance }\end{array}$ & Conclusion & $\begin{array}{l}\text { Intercept } \\
\text { and Trend }\end{array}$ & $\begin{array}{c}\text { Level of } \\
\text { Significance }\end{array}$ & Conclusion \\
\hline LGDP & $\begin{array}{c}-3.696174 \\
(2.9591)\end{array}$ & $5 \%$ & $\mathrm{I}(1)$ & $\begin{array}{c}-3.626057 \\
(-3.5614)\end{array}$ & $5 \%$ & $\mathrm{I}(1)$ \\
\hline LXHEA & $\begin{array}{c}-6.600216 \\
(-3.6576)\end{array}$ & $1 \%$ & $\mathrm{I}(1)$ & $\begin{array}{c}-8.501170 \\
(-4.2826)\end{array}$ & $1 \%$ & $\mathrm{I}(1)$ \\
\hline LELEC & $\begin{array}{c}-3.799400 \\
(-3.6576)\end{array}$ & $1 \%$ & $\mathrm{I}(1)$ & $\begin{array}{l}-3.693575 \\
(-3.5614)\end{array}$ & $5 \%$ & $\mathrm{I}(1)$ \\
\hline LCROL & $\begin{array}{l}-4.39776 \\
(-3.6576)\end{array}$ & $5 \%$ & $\mathrm{I}(1)$ & $\begin{array}{l}-4.455214 \\
(-4.2826)\end{array}$ & $1 \%$ & $\mathrm{I}(1)$ \\
\hline LGUT & $\begin{array}{l}-4.39796 \\
(-3.6576)\end{array}$ & $1 \%$ & $\mathrm{I}(1)$ & $\begin{array}{c}-4.910124 \\
(-4.2826)\end{array}$ & $1 \%$ & $\mathrm{I}(1)$ \\
\hline LMSS & $\begin{array}{c}-3.534403 \\
(-2.9591)\end{array}$ & $5 \%$ & $\mathrm{I}(1)$ & $\begin{array}{c}-3.457724 \\
(-3.2138)\end{array}$ & $10 \%$ & $\mathrm{I}(1)$ \\
\hline
\end{tabular}

\section{Cointegration Test}

Consider the following levels VAR, with $X_{t}$ defined as the log of LGDP, LXHEA, LELEC, LCROL, LGUT and LMSS

$$
X_{t}=c+\sum_{j=1}^{\mathrm{p}} \Gamma_{j} X_{t-\mathrm{j}}+\varepsilon_{j} .
$$

If the variable in $X_{t}$ are I(1), the VAR in equation (4) is not a stationary one. If there is no co-integration, statistical inference is not possible using the usual tests. Given this, it is necessary to first difference the series and therefore estimates a first difference VAR of the form:

$$
\Delta X_{t}=c+\sum_{j=1}^{\mathrm{p}} \Gamma_{j} \Delta X_{t-\mathrm{j}}+\varepsilon_{j} .
$$

When there is co-integration, there is at least one linear combination of $X_{t}$, also known as co-integrating vector that gives rise to the stationary variable. If this is the case, the VAR in equation (5) can be re written as

$$
\Delta X_{t}=c+\sum_{j=1}^{\mathrm{p}} \Gamma_{j} \Delta X_{t-\mathrm{j}}+\Pi X_{t-1}+\varepsilon_{t} .
$$

In equation (6), $\Pi$ is a rank $r$ matrix that can be decomposed as:

$$
\Pi=\alpha \beta \text { ! }
$$

Where $\alpha$ is a $3 \times r$ loading matrix and $\beta$ is a $3 \times r$ matrix of co-integrating vectors, $r$ being the number of co-integrating vectors. Following Johansen (1991) procedure, the number of co-integrating vectors was tested using the co-integrated VAR as in (6). Table 4 below shows the co-integration results.

Co-integration implies that causality exists between a series but it does not indicate the direction of causal relationship. The Johansen co-integration results revealed that there 
Table 4. Johansen cointegration results

\begin{tabular}{ccccc}
\hline \multicolumn{5}{c}{ Series: LGDP LELEC LCROL LGUT LXHEA } \\
\hline & \multicolumn{5}{c}{ Lags interval: 1 to 2} \\
\hline Likelihood & 5 Percent & 1 Percent & Hypothesized \\
\hline 0.665117 & Ratio & Critical Value & Critical Value & No. of CE(s) \\
\hline 0.469803 & 77.10520 & 68.52 & 76.07 & None ** \\
\hline 0.401912 & 23.19197 & 47.21 & 54.46 & At most 1 \\
\hline 0.147686 & 7.587723 & 29.68 & 35.65 & At most 2 \\
\hline 0.081456 & 2.633927 & 15.41 & 20.04 & At most 3 \\
\hline
\end{tabular}

$*(* *)$ denotes rejection of the hypothesis at $5 \%(1 \%)$ significance level

L.R. test indicates 1 cointegrating equation(s) at 5\% significance level

is long run relationship between the various forms of energy consumption (electricity consumption, crude oil consumption and gas consumption), health expenditure broad money supply and economic growth in Nigeria.

\section{Granger Causality Test}

The Granger (1969) test is traditionally used to test for causal relationship between two variables. This has widely been used in relevant literatures to test for causality relationships. The Granger (1969) test states that, if past values of a variables $Y$ significantly contribute to forecast the value of another variables $X$, then $Y$ is said to Granger cause $X$ and vice versa. The test is based on the equations below.

$$
\begin{aligned}
& Y_{t}=\gamma_{0}+\sum_{z=1}^{\mathrm{p}} \gamma_{z} Y_{t-\mathrm{z}}+\sum_{i=1}^{q} \lambda_{\mathrm{i}} X_{t-1}+\mu_{t} . \\
& X_{t}=\varphi_{0}+\sum_{z=1}^{\mathrm{p}} \delta_{z} X_{t-\mathrm{z}}+\sum_{i=1}^{q} \psi_{\mathrm{i}} Y_{t-1}+\varepsilon_{t} .
\end{aligned}
$$

Where $Y_{t}$ and $X_{t}$ are the variables to be tested $\mu_{t}$ and $\varepsilon_{t}$ are respective error terms and $t$ denotes time period $z$ and i's are the number of lags. The null hypothesis is $\lambda_{\mathrm{i}}=\psi_{\mathrm{i}}=0$ for all i's versus the alternative hypothesis that $\lambda_{i} \neq 0$ and $\psi_{i} \neq 0$ for at least some i's if the coefficient $\lambda_{\mathrm{i}}$ are statistically significant but $\psi_{\mathrm{i}}$ are not then $X$ causes $Y$ and vice versa. But if both coefficients are significant then causality runs both ways. The result for Granger causality is shown in Table 5.

Using various forms of proxies for energy demand in the estimation in addition to government activities proxied by health expenditure, monetary policy proxied by broad money supply, it was found that there is unidirectional causality between electricity demand and economic growth with causality running from electricity demand to economic growth. Unidirectional relationship was also found between domestic crude oil demand and economic growth as well as between gas utilization and economic growth in Nigeria. While causality runs from gas utilization to economic growth, it runs from economic growth to domestic consumption of crude oil in Nigeria. Furthermore, it was 
Table 5. Multivariate pair wise Granger causality result

\begin{tabular}{|c|c|c|c|}
\hline \multicolumn{4}{|c|}{ Multivariate Pairwise Granger Causality Tests } \\
\hline Null Hypothesis: & Obs & F-Statistic & Probability \\
\hline LELEC does not Granger Cause LGDP & 34 & 4.38584 & 0.04479 \\
\hline LGDP does not Granger Cause LELEC & & 0.14728 & 0.70386 \\
\hline LCROL does not Granger Cause LGDP & 34 & 0.49409 & 0.48753 \\
\hline LGDP does not Granger Cause LCROL & & 6.23302 & 0.01826 \\
\hline LGUT does not Granger Cause LGDP & 34 & 2.54486 & 0.12114 \\
\hline LGDP does not Granger Cause LGUT & & 0.67239 & 0.41869 \\
\hline LMSS does not Granger Cause LGDP & 34 & 3.24487 & 0.08171 \\
\hline LGDP does not Granger Cause LMSS & & 0.13529 & 0.71559 \\
\hline LXHEA does not Granger Cause LGDP & 34 & 0.08772 & 0.76913 \\
\hline LGDP does not Granger Cause LXHEA & & 3.28896 & 0.07976 \\
\hline LCROL does not Granger Cause LELEC & 34 & 0.64358 & 0.42873 \\
\hline LELEC does not Granger Cause LCROL & & 3.38061 & 0.07589 \\
\hline LGUT does not Granger Cause LELEC & 34 & 9.31540 & 0.00473 \\
\hline LELEC does not Granger Cause LGUT & & 0.93941 & 0.34018 \\
\hline LMSS does not Granger Cause LELEC & 34 & 6.22472 & 0.01833 \\
\hline LELEC does not Granger Cause LMSS & & 0.03751 & 0.84773 \\
\hline LXHEA does not Granger Cause LELEC & 34 & 4.02345 & 0.05396 \\
\hline LELEC does not Granger Cause LXHEA & & 2.27730 & 0.14174 \\
\hline LGUT does not Granger Cause LCROL & 34 & 11.7514 & 0.00179 \\
\hline LCROL does not Granger Cause LGUT & & 5.61411 & 0.02445 \\
\hline LMSS does not Granger Cause LCROL & 34 & 7.59493 & 0.00986 \\
\hline LCROL does not Granger Cause LMSS & & 0.02777 & 0.86876 \\
\hline LXHEA does not Granger Cause LCROL & 34 & 1.28101 & 0.26668 \\
\hline LCROL does not Granger Cause LXHEA & & 6.00509 & 0.02031 \\
\hline LMSS does not Granger Cause LGUT & 34 & 11.3154 & 0.00212 \\
\hline LGUT does not Granger Cause LMSS & & 0.01967 & 0.88941 \\
\hline LXHEA does not Granger Cause LGUT & 34 & 3.43140 & 0.07383 \\
\hline LGUT does not Granger Cause LXHEA & & 2.43642 & 0.12904 \\
\hline LXHEA does not Granger Cause LMSS & 34 & 0.80943 & 0.37545 \\
\hline LMSS does not Granger Cause LXHEA & & 5.90848 & 0.02126 \\
\hline
\end{tabular}


found that money supply Granger caused economic growth with no feedback effect. On the other hand, economic growth Granger causes health expenditure with no feed back effect. As regards electricity demand and economic growth, the result conforms to the earlier result got by Ighodaro and Ovenseri-Ogbomo (2008) and contrary to the earlier results by Omotor (2008) and Olusegun (2008). The overall result reveals that different sources of energy have different causality relationship with economic growth in Nigeria.

\section{Conclusion and Policy implications of Results}

Attempt was made in this paper to re-examine the direction of causality between energy demand and economic growth in Nigeria using domestic crude oil demand, gas utilization and electricity demand as proxies for energy consumption. Included in the estimation is government activity proxied by health expenditure and monetary policy proxied by broad money supply. It was established that there is unidirectional causality between electricity demand and economic growth, domestic crude oil consumption and economic growth as well as between gas utilization and economic growth in Nigeria.

The paper has important policy implications. Energy conservation policy regarding domestic consumption of crude oil would not harm economic growth while energy conservation policy regarding gas utilization would harm economic growth in Nigeria. However, energy policy regarding electricity consumption should be implemented in such a way that it further boosts economic growth as well as create investment opportunities in Nigeria.

\section{References}

Abosedra, S.; Baghestani, H. 1989. New evidence on the causal relationship between United States energy consumption and gross national product, Journal of Energy and Development 14(2): 285-292.

Akarca, A. T.; Long, T. V. 1980. On the relationship between energy and GNP: a reexamination, Journal of Energy and Development 5(2): 326-331.

Altinay, G.; Karagol, E. 2005. Electricity consumption and economic growth: evidence from Turkey, Energy Economics 27(6): 849-856. doi:10.1016/j.eneco.2005.07.002

Aqeel, A.; Butt, M. S. 2001. The relationship between energy consumption and economic growth in Pakistan, Asia - Pacific Development Journal 8 (2): 101-109.

Alper, O.; Atilla, C. 2007. Multi-scale causality between energy consumption and GNP in emerging markets: evidence from Turkey, Investment Management and Financial Innovations 4(6): $60-70$.

Bannered, A.; Dolado, J.; Galbraith, J.W.; Hendry, D. F. 1993. Co-integration, error correction, and the econometric analysis of nonstationary data. Oxford: Oxford University Press.

Berndt, E. R. 1978. Aggregate energy, efficiency, and productivity measurement, Annual Review of Energy 3: 225-273. doi:10.1146/annurev.eg.03.110178.001301

Çelik, S.; Özerkek, Y. 2009. Panel cointegration analysis of consumer confidence and personal consumption in the European Union, Journal of Business Economics and Management 10(2): 161-168. doi:10.3846/1611-1699.2009.10.161-168

Central Bank of Nigeria 2000. The changing structure of the Nigerian economy and implications for development, Research Department, Central Bank of Nigeria; Realm Communications Ltd, Lagos August. 
Central Bank of Nigeria 2003. Statistical Bulletin, Vol. 14, December.

Central Bank of Nigeria 2004. Statistical Bulletin, Vol. 15, December.

Central Bank of Nigeria 2007. Statistical Bulletin, Vol. 18, December.

Cheng, Y.; Wong, J. F. 2001. Poverty, energy and economic growth in Singapore. Department of Economics, National University of Singapore, 37.

Cheng, S. B.; Lai, T. W. 1997. An investigation of co-integration and causality between energy consumption and economic activity in Taiwan, Energy Economics 19(4): 435-444.

doi:10.1016/S0140-9883(97)01023-2

Cheng, B. S. 1999. Causality between energy consumption and economic growth in India: an application of cointegration and error-correction modeling, Indian Economic Review 34(1): 39-49.

Chontanawat, J.; Hunt, L.; Pierse, R. 2006. Causality between energy consumption and GDP: evidence 30 OECD and 78 Non-OECD countries. Surrey Energy Economics Centre, SEEC, Working Papers, No. 113.

Erol, U.; Yu, E. S. H. 1988. On the causal relationship between energy and income for industrialized countries, The Journal of Energy and Development 13(1): 113-122.

Granger, C. W. J. 1986. Developments in the study of cointegrated economic variables, Oxford Bulletin of Economics and Statistics 48(3): 213-228.

Federal Republic of Nigeria [online]. 2006. Federal ministry of power and steel: renewable electricity policy guidelines [cited 18 January 2010]. Available from Internet: <http:www.iceednigeria.org/REAP-postconference.pdf $>$.

Ferguson, R.; Wilkinson, W.; Hill, R. 2000. Electricity use and economic development, Energy Policy 28(13): 923-934. doi:10.1016/S0301-4215(00)00081-1

Ghali, K. H.; El-Sakka, M. I. T. 2004. Energy use and output growth in Canada: a multivariate cointegration analysis, Energy Economics 26(2): 225-238. doi:10.1016/S0140-9883(03)00056-2

Glasure, Y. U.; Lee, A. R. 1997. Cointegration, error-correction, and the relationship between GDP and energy: the case of South Korea and Singapore, Resource and Energy Economics 20(1): 17-25. doi:10.1016/S0928-7655(96)00016-4

Glasure, Y. U. 2002. Energy and national income in Korea: further evidence on the role of omitted variables, Energy Economics 24(4): 355-365. doi:10.1016/S0140-9883(02)00036-1

Ghosh, S. 2002. Electricity consumption and economic growth in India, Energy Policy 30(2): 125-129. doi:10.1016/S0301-4215(01)00078-7

Granger, C. W. J. 1969. Investigating causal relations by econometric models and cross-spectral methods, Econometrica 37(3): 424-438. doi:10.2307/1912791

Granger, C. W. J. 1986. Developments in the Study of cointegrated economic variables, Oxford Bulletin of Economics and Statistics 48: 213-228.

Hannesson, R. 2002. Energy use and GDP growth, 1950-97, OPEC Review 26(3): 215-233. doi:10.1111/1468-0076.00115

Hondroyiannis, G.; Lolos, S.; Papapetrou, E. 2002. Energy consumption and economic growth: assessing the evidence from Greece, Energy Economics 24(4): 319-336.

doi:10.1016/S0140-9883(02)00006-3

Hwang, D. B. K.; Gum, B. 1992. The causal relationship between energy and GNP: the case of Taiwan, The Journal of Energy and Development 16(2): 219-226.

Ighodaro, C. A. U.; Ovenseri-Ogbomo, F 2008. Causality relationship between energy demand and economic growth in Nigeria, The Indian Journal of Economics 89(353) [online] [cited 18 January 2010]. Available from Internet: $<$ http://www.indianjournalofeconomics.com/october2008. htm\#2>. 
Johansen, S. 1991. Estimation and Hypothesis-Testing of cointegration vectors in Gaussian Vector autoregressive models, Econometrica 59(6): 1551-1580. doi:10.2307/2938278

Jumbe, C. B. L. 2004. Co-integration and causality between electricity consumption and GDP: empirical evidence from Malawi, Energy Economics 26(1): 61-68.

doi:10.1016/S0140-9883(03)00058-6

Kraft, J.; Kraft, A. 1978. On the relationship between energy and GNP, Journal of Energy and Development 3: 401-403.

Masih, A. M. M.; Masih, R. 1996. Energy consumption, real income and temporal causality; results from a multi-country study based on cointegration and error correction modeling technique, Energy Economics 18(3): 165-183. doi:10.1016/0140-9883(96)00009-6

Masih, A. M. M.; Masih, R. 1997. On temporal causal relationship between energy consumption, real income and prices; some new evidence from Asian energy dependent NICs based on a multivariate cointegration / vector error correction approach, Journal of Policy Modeling 19(4): 417-440. doi:10.1016/S0161-8938(96)00063-4

Masih, A. M. M.; Masih, R. 1998. A multivariate cointegrated modeling approach in testing temporal causality between energy consumption, real income and prices with an application to two Asian LDCs, Applied Economics 30(10): 1287-1298. doi:10.1080/000368498324904

Nachane, D. M.; Nadkarni, R. M.; Karnik, A. V. 1988. Co-integration and causality testing of the Energy-GDP relationship: a cross-country study, Applied Economics 20(11): 1511-1531. doi:10.1080/00036848800000083

Oh, W.; Lee, K. 2004. Causal relationship between energy consumption and GDP revisited: the case of Korea 1970-1999, Energy Economics 26(1): 51-59. doi:10.1016/S0140-9883(03)00030-6 Olayide, S. O. 1976. Economic Survey of Nigeria (1960 - 1975), Aromolaran Publishing Company Ltd, Ibadan, Nigeria.

Olusegun, O.A. 2008. Energy consumption and economic growth in Nigeria. A bound testing cointegration approach, Journal of Economic Theory 2(4): 118-123.

Omotor, D. G. 2008. Causality between energy consumption and economic growth in Nigeria, Pakistan Journal of Social Sciences 5(8): 827-835

Pesaran, H. M.; Shin, Y.; Smith, R. J. 2001. Bounds testing approaches to the analysis of long-run relationships, Journal of Applied Econometrics 16(3): 289-326. doi:10.1002/jae.616

Proops, J. L. R. 1984. Modeling the energy-output ratio, Energy Economics 6(1): 47-51. doi:10.1016/0140-9883(84)90043-4

Randle, J. K. 2007. The servant leader (5), Vanguard [online] 23(60388), August $9^{\text {th }}$ [cited 10 January 2010]. Available from Internet: <http://allafrica.com/stories/200708100210.html>.

Rasche, R. H.; Tatom, J. A. 1977. The effects of the new energy regime on economic capacity, production and prices, Federal Reserve Bank of St Louis Review 59(5): 2-12.

Reddy, M.; Yanagida, J. F. 1998. Energy price shocks, input substitution and developmental implications: a translog model applied to Fiji, Journal of Asia Pacific Economy 3(1): 21-34.

Sica, E. 2007. Causality between Energy and Economic Growth: the Italian Case, Quaderno No. 3.

Soytas, U.; Sari, R. 2003. Energy consumption and GDP: causality relationship in G-7 countries and emerging markets, Energy Economics 25(1): 33-37. doi:10.1016/S0140-9883(02)00009-9

Sari, R.; Soytas, U. 2004. Disaggregate energy consumption, employment, and income in Turkey, Energy Economics 26: 335-344. doi:10.1016/j.eneco.2004.04.014

Squalli, J.; Wilson, K. 2006. A bound analysis of electricity consumption and economic growth in the GCC, Economic and Policy Research Unit Working Paper Series No. 06-09. 
Toda, H. Y.; Yamamoto, T. 1995. Statistical inference in vector autoregressions with possibly integrated process, Journal of Econometrics 66(1-2): 225-250. doi:10.1016/0304-4076(94)01616-8

Wolde-Rufael, Y. 2004. Disaggregated Industrial Energy Consumption and GDP: The Case of Shanghai, 1952-1999, Energy Economics 26(1): 69-75. doi:10.1016/S0140-9883(03)00032-X

Yang, H.-Y. 2000. A note on the causal relationship between energy and GDP in Taiwan, Energy Economics 22(3): 309-317. doi:10.1016/S0140-9883(99)00044-4

Yu, E. S. H.; Hwang, B.-K. 1984. The relationship between energy and GNP: further results, Energy Economics 6(3): 186-190. doi:10.1016/0140-9883(84)90015-X

Yu, E. S. H.; Choi, J. Y. 1985. The causal relationship between energy and GNP: an international comparison, Journal of Energy Development 10: 249-272.

Yu, E. S. H.; Jin, J. C. 1992. Cointegration tests of energy consumption, income and employment, Resource and Energy 14: 259-266. doi:10.1016/0165-0572(92)90010-E

\section{ENERGIJOS SUVARTOJIMO IR EKONOMINIO AUGIMO TARPUSAVIO RYŠYS: NIGERIJOS ATVEJO EMPIRINIS TYRIMAS}

\section{A. U. Ighodaro}

Santrauka

Tyrinejamas energijos suvartojimo ir ekonominio augimo tarpusavio ryšys bei priežastingumas Nigerijoje, remiantis 1970-2005 m. statistiniais duomenimis. Naujai, lyginant su ankstesniais Nigerijos tyrimais, parenkami energijos vartojimo matavimo būdai (elektros energijos paklausa, vietinès naftos žaliavos suvartojimas, dujų utilizavimas). Straipsnyje atsižvelgiama į socialinę ir monetarinę valstybès politika, kurios atspindi valstybės gerovę. Pritaikius Johansen tarpusavio priklausomybès metodą buvo gauta, kad tarp visų energijos vartojimą atspindinčių rodiklių ir ekonominio augimo yra netiesioginis priežastinis ryšys. Manoma, kad elektros bei dujų naudojimo apribojimas stabdytų Nigerijos ekonomini augima, o naftos žaliavos vartojimo masto mažinimas nepaveiktų tolesnès šalies plètros.

Reikšminiai žodžiai: ekonominis augimas, dujų utilizavimas, naftos vartojimas, Johansen tarpusavio priklausomybès metodas.

Clement Atewe U. IGHODARO is currently a staff of the Department of Economics, University of Lagos, Akoka, Yaba, Lagos State, Nigeria. He received his B.Sc. (Hons) and M.Sc. respectively in Economics, M.B.A. and PhD in Economics from the University of Benin, Benin City, Edo State, Nigeria. His $\mathrm{PhD}$ programme in Economics at the University of Benin was under the scholarship of the African Economic Research Consortium (AERC), Nairobi, Kenya. He was a staff of the National Business and Technical Examinations Board (NABTEB), National Headquarters, Benin City, Edo State, Nigeria for eight years in the department of Research and Quality Assurance (RQA) Department formerly Monitoring, Research and Statistics (MRS) Department. He later resigned as Senior Research Officer for an appointment at the department of Economics, University of Lagos as a lecturer. He specializes in economic theory, economic development and applied econometrics. At present, he lectures economic theory at both graduate and undergraduate levels. He is a member of African Economic Research Consortium (AERC), Nairobi, Kenya and Poverty and Economic Policy (PEP) Research Network, Quebec, Canada. 